\title{
PENELUSURAN MIKROORGANISME PENGHASIL ANTIBIOTIKA DARI LIMBAH AIR DANGKE KABUPATEN ENREKANG SULAWESI SELATAN
}

\author{
Fitriana, Jurianti \\ Fakultas Farmasi Universitas Muslim Indonesia \\ Email : fitrianapipie@yahoo.co.id
}

\begin{abstract}
Has been studied antibiotic-producing microbial isolation from waste water districs dangke enrekang. Preliminary studies carried out using the method of casting on medium Nutrient Agar (NA) and Potato Dextrosa Agar (PDA) with dilutions of $10^{-1}$ to $10^{-5}$. The results of four isolates of microbes are active in NA medium and four isolatesPDA medium, and then observed in macroscopic and microscopic. Furthermore, bacterial and fungal isolates was purified by the method of quadrants on each medim Nurien Agar (NA) and Potato Dextrosa Agar (PDA). To produce antibiotis from microbial fermentation performed using Yeast Maltose Broth medium (MYB). The results of testing the activity of an antibiotic fermentation with agar diffusion method. The results showed that the bacterial isolates I and II Salmonella typhi and is active againts Candida albicans. Bacterial isolates I, II, III, and IV, were active againts Staphylococcus epidermis, Streptococcus mutans, Pseudomonas aeruginosa, Vibrio sp, Escherichia coli, Bacillus subtilis and Staphylococcus aureus. I fungal isolates active against Salmonella typhi. II and IV of fungal isolates active against Pseudomonas aeruginosa. IV fungal isolates active against Vibriosp, Escherichiacoli and Stapylococcusaureus.
\end{abstract}

Key word : Studied Antibiotic-Producing, Waste Water, Dangke, Enrekang

\section{PENDAHULUAN}

Mikroorganisme mempunyai pengaruh yang besar dalam ilmu kesehatan karena selain dapat menyebabkan infeksi, juga dapat digunakan untuk menghasilkan berbagai senyawa-senyawa yang dapat mengobati infeksi. Senyawa tersebut dikenal sebagai antibiotika.

Kebutuhan antibiotika baru masih sangat diperlukan, terutama yang efektif melawan bakteri resisten, virus, protozoa, fungi atau tumor. Untuk mendapatkan antibiotik baru, para peneliti banyak melakukannya berbagai cara seperti biotransformasi senyawa-senyawa tertentu dengan bantuan mikroba atau membuat derivat antibiotika semisintetik, mutasi strain penghasil antibiotika atau mencari senyawa antibiotika baru dari mikroba yang ada di alam (Suwandi, 1989). Sumber penghasil antibiotika antara lain berasal dari tanah, air laut, 
lumpur, kompos, limbah domestik, bahan makanan busuk dan lainnya (Suwandi, 1989).

Dangke merupakan jenis makanan yang bergizi dan khas, yang terdapat dan dikenal di Kabupaten Enrekang Propinsi Sulawesi Selatan, yang dibuat dari susu kerbau atau susu sapi. Dangke berasal dari bahasa belanda yang didengar oleh rakyat setempat waktu orang belanda melihat dan menerima jenis makanan yang dibuat dari susu kerbau atau susu sapi. Selanjutnya mengatakan "Dangk Well" yang artinya terima kasih. Kata "Dangk" inilah yang akhirnya dipakai untuk nama dangke (Djide, 1991).

Dangke dibuat melalui susu sapi atau susu kerbau yang diperah dan belum pecah, lalu dipanaskan dengan api kecil sampai mendidih, kemudian di dalam susu ditambahkan dengan 1 sendok teh enzim papain (Papain Kasar). Penambahan yang berlebihan dapat menyebabkan dangke terasa pahit (Djide, 1991).

Tujuan pengolahan susu menjadi dangke agar dapat disimpan lebih lama dan mencegah terjadinya kerusakan pada air susu. Selain itu untuk mempertahankan kualitas dangke biasanya dangke direndam di dalam larutan garam jenuh selama satu jam dan dikeringkan pada suhu kamar selama 160 menit serta dibungkus dengan plastik. Dengan cara ini dangke dapat bertahan untuk jangka waktu dua bulan. Dangke merupakan bahan pangan dengan nilai gizi yang tinggi. Dangke kerbau terdiri dari air 47, 75\%; abu 2,32\%; lemak 33,89\%; protein $17,01 \%$; serta komponen-komponen lainnya dalam jumlah kecil yakni vitamin dan mineral (Marzoeki, dkk., 1978).

Dangke merupakan produk olahan susu yang menyerupai keju, dimana susu merupakan bahan makanan yang sempurna karena hampir mengandung semua zat yang diperlukan oleh tubuh yaitu protein, lemak dan laktosa. Namun demikian tingginya nilai gizi bahan tersebut menyebabkan susu merupakan substrat yang baik untuk pertumbuhan mikroorganisme (Fardiaz, 1989).

Dari uraian diatas maka perlu diadakan penelitian mengenai penelusuran mikroorganisme yang terdapat dalam limbah air dangke yang berpotensi sebagai antibiotika.

\section{METODE PENELITIAN}

\section{Sterilisasi alat}

Alat-alat yang digunakan terlebih dahulu dicuci lalu dibilas dengan air suling, selanjutnya alat-alat gelas dikeringkan lalu disterilkan 
dengan menggunakan oven selama 2 jam pada suhu $180^{\circ} \mathrm{C}$. Adapun alatalat plastik atau yang tidak tahan panas disterilkan dalam otoklaf selama 15 menit pada suhu $121^{\circ} \mathrm{C}$. Ose disterilkan dengan cara dipijarkan pada lampu spiritus.

\section{Pengambilan dan pengolahan sampel}

\section{Pengambilan Sampel}

Sampel limbah air dangke diambil dari tempat pembuatan Dangke yang berada di Kabupaten Enrekang. Sulawesi selatan.

\section{Pembuatan suspensi sampel}

Sampel limbah air dangke dipipet $1 \mathrm{ml}$, lalu dimasukkan ke dalam botol pengencer dan dicukupkan dengan air suling steril hingga $10 \mathrm{ml}$ dan dibuat pengenceran hingga pengenceran $10^{-5}$.

\section{Pembiakan Mikroba Limbah air Dangke}

Suspensi sampel dari setiap pengenceran diambil $1 \mathrm{ml}$ secara aseptis, kemudian dimasukkan ke cawan petri lalu ditambahkan medium NA. kemudian dihomogenkan dengan cara memutar cawan membentuk angka delapan. Diinkubasi 1-5 hari pada suhu $37^{\circ} \mathrm{C}$. Kemudian diulang kembali cara kerja diatas pada medium PDA untuk setiap pengenceran. Diinkubasi 1- 8 hari pada suhu kamar.

\section{Seleksi dan Isolasi Biakan}

Setelah diinkubasi dilakukan pengamatan terhadap koloni yang tumbuh yang memperlihatkan adanya hambatan berupa daerah bening disekelilingnya. Koloni ini selanjutnya diisolasi dan dipindahkan pada agar miring sebagai stok.

\section{Makroskopik dan Mikroskopik}

\section{Makroskopik}

Diambil satu ose isolat, diinokulasikan dalam $10 \mathrm{ml}$ air suling steril. Lalu diambil 0,1 $\mathrm{ml}$ dimasukkan ke dalam botol pengencer dan dicukupkan dengan air suling steril hingga $10 \mathrm{ml}$ sehingga diperoleh pengenceran $10^{-1}$ dan dibuat pengenceran hingga $10^{-5}$.

Isolat dari setiap pengenceran diambil $0,1 \mathrm{ml}$ secara aseptis, kemudian dimasukkan ke cawan petri lalu ditambahkan 9,9 ml medium NA kemudian dihomogenkan dengan cara memutar cawan petri membentuk angka delapan. Diinkubasi 1-5 hari pada suhu $37^{\circ} \mathrm{C}$.

Kemudian diulang kembali cara kerja di atas pada medium PDA untuk setiap pengenceran. Diinkubasi 1-8 hari pada suhu kamar $\left( \pm 27^{\circ} \mathrm{C}\right)$. Pengamatan dilakukan dengan melihat bentuk koloni, tepi koloni, elevasi 
koloni, warna koloni, struktur dalam koloni.

\section{Mikroskopik}

Disiapkan objek gelas dan deck gelas yang telah dibersihkan dan dibebaslemakkan dengan etanol $70 \%$. Dibuat film yang tipis pada permukaan objek gelas dengan menggunakan ose bulat. Film dikeringkan di udara, kemudian difiksasi dengan cara menyentuhkan permukaan kaca objek gelas pada lampu spiritus. Setelah didinginkan, preparat lalu ditambahkan dengan cat A sebanyak 1-2 tetes, didiamkan selama 30 detik lalu dicuci dengan air mengalir dan dikeringkan dengan tissue.

Setelah kering dilakukan perlakuan yang sama seperti pada penambahan cat $A$ secara bergantian mulai dari penambahan cat B (30 detik), cat $\mathrm{C}$ (20 detik), dan cat D (30 detik). Setelah itu, preparat siap untuk diamati di bawah mikroskop. Pengamatan dilakukan dengan melihat bentuk sel dan warna isolat bakteri. Warna ungu menunjukkan bakteri Gram positif, sedangkan warna merah menunjukkan bakteri Gram negatif.

\section{Pemurnian isolat mikroba}

Setiap isolat yang berbeda dimurnikan dengan metode kuadran untuk memperoleh isolat yang tunggal.
Biakan murni tersebut lalu dipindahkan pada agar miring sebagai stok.

\section{Fermentasi Biakan Murni}

Koloni biakan murni diambil satu ose, diinokulasikan dalam medium NA miring lalu diinkubasi pada suhu $37^{\circ} \mathrm{C}$ selama $1 \times 24$ jam untuk bakteri dan PDA miring pada suhu kamar selama 3 × 24 jam untuk jamur, kemudian disuspensikan dengan 2,5 $\mathrm{ml}$ larutan $\mathrm{NaCl}$ fisiologis dan diinokulasikan dalam $10 \mathrm{ml}$ medium pembenihan cair Maltosa Yeast Ekstrak Broth. Lalu diinkubasi pada suhu kamar selama $1 \times 24$ jam dan dikocok menggunakan shaker dengan kecepatan 200 rpm.

\section{Penyiapan mikroorganisme uji Peremajaan Mikroba uji}

Mikroba uji yang digunakan dalam penelitian ini meliputi Basillus subtilis, Escherichia coli, Staphylococcus aureus, Salmonella typhi, Pseudomonas aeruginosa, Vibrio sp, Streptococcus mutans, Staphylococcus epidermidis, dan Candida albicans. Stok bakteri dan jamur yang berasal dari Laboratorium Mikrobiologi Farmasi UMI masingmasing diambil satu ose lalu diinokulasikan dengan cara digoreskan pada medium NA miring dan PDA miring lalu diinkubasikan selama $1 \mathrm{x}$ 
24 jam pada suhu $37^{\circ} \mathrm{C}$ untuk bakteri dan $3 \times 24$ jam pada suhu $27^{\circ} \mathrm{C}$ untuk jamur.

\section{Pembuatan Suspensi Mikroba Uji}

Mikroba uji yang telah diremajakan disuspensikan dengan larutan $\mathrm{NaCl}$ fisiologis ( $\mathrm{NaCl} 0,9 \%$ ) lalu diukur transmitannya 25\% T untuk bakteri dan $75 \% \mathrm{~T}$ untuk jamur menggunakan spektrofotometer UVVisibel.

\section{Pemeriksaan aktivitas antibiotika.}

Pengujian aktivitas antibiotika yang umum dilakukan ialah cara difusi agar menggunakan medium GNA.

Medium GNA diambil sebanyak $10 \mathrm{ml}$ dan ditambahkan dengan $20 \mu \mathrm{l}$ suspensi mikroba, kemudian dimasukkan dalam cawan petri, dibenamkan dalam hasil fermentasi kemudian piper discs diletakkan diatas permukaan medium yang memadat.
Kemudian diinkubasi pada suhu $37^{\circ} \mathrm{C}$ selama 1 × 24 jam untuk bakteri dan pada suhu kamar selama 3 × 24 jam untuk jamur, lalu dimati dan diukur zona hambatan yang terbentuk.

\section{HASIL PENELITIAN}

Isolasi mikroba dari limbah air dangke Kabupaten Enrekang.

Berdasarkan hasil penelitian yang telah dilakukan diperoleh 4 koloni bakteri yang membentuk zona hambat dari pengenceran $10^{-1}, 10^{-2}, 10^{-3}, 10^{-4}$, serta 4 koloni jamur yang juga membentuk zona hambatan dari pengenceran $10^{-1}, 10^{-2}, 10^{-5}$.

\section{Makroskopik.}

Koloni yang menunjukkan zona hambatan juga diamati secara makroskopik dengan melihat warna koloni, bentuk koloni, tepi koloni, elevasi koloni, dan struktur dalam koloni.

Tabel 1. Hasil Makroskopik Isolat Bakteri

\begin{tabular}{cccccc}
\hline Kode Bakteri & Warna & Bentuk & Tepi & Elevasi & $\begin{array}{c}\text { Struktur } \\
\text { Dalam }\end{array}$ \\
\hline JB 1 & Putin & $\begin{array}{c}\text { Irregular and } \\
\text { Spreading } \\
\text { Irregular and } \\
\text { Spreading }\end{array}$ & Irregular & Convex & Opaque \\
JB 2 & Kuning & Wogular & Umbonate & Opaque \\
JB 3 & Kuning & Round & $\begin{array}{c}\text { Wavy } \\
\text { (Undulate) }\end{array}$ & Convex & Opaque \\
JB 4 & Putih & $\begin{array}{c}\text { Irregular and } \\
\text { Spreading }\end{array}$ & Ciliate & Convex & Opaque \\
\hline
\end{tabular}

Keterangan :

JB 1 : Isolat bakteri ke-1

JB 3 : Isolat bakteri ke-3

JB 2 : Isolat bakteri ke-2

JB 4 : Isolat bakteri ke-4 
Tabel 2. Hasil Makroskopik Isolat Jamur

\begin{tabular}{cccccc}
\hline $\begin{array}{c}\text { Kode } \\
\text { Jamur }\end{array}$ & Warna & Bentuk & Tepi & Elevasi & $\begin{array}{c}\text { Struktur } \\
\text { Dalam }\end{array}$ \\
\hline JJ 1 & Hijau Keabu-abuan & Complex & Ciliate & Umbonate & Filamentous \\
JJ 2 & Hijau tua & $\begin{array}{c}\text { Round } \\
\text { Round with } \\
\text { JJ 3 }\end{array}$ & Ciliate & Convex & Filamentous \\
Riliate & Umbonate & Filamentous \\
JJ 4 & Round with & Wavy & Convex & Filamentous \\
\hline
\end{tabular}

Keterangan :

JJ 1 : Isolat jamur ke-1

JJ 2 : Isolat jamur ke-2

JJ 3 : Isolat jamur ke-3

JJ 4 : Isolat jamur ke-4

\section{Pengecatan Gram}

Pengamatan dilakukan dengan

melihat bentuk sel dan warna isolat bakteri. Untuk bakteri Gram positif menunjukan warna ungu, sedangkan bakteri Gram negatif menunjukan warna merah.

Tabel 3. Hasil Pengecatan Gram Isolat Bakteri

\begin{tabular}{ccccc}
\hline \multirow{2}{*}{ No } & \multirow{2}{*}{ Kode Bakteri } & \multicolumn{3}{c}{ Mikroskopik } \\
\cline { 2 - 5 } & & Warna & Bentuk & Keterangan \\
\hline 1 & JB 1 & Merah & Kokus & Gram negatif \\
2 & JB 2 & Merah & Kokus & Gram negatif \\
3 & JB 3 & Merah & Kokus & Gram negatif \\
4 & JB 4 & Merah & Kokus & Gram nagatif \\
\hline
\end{tabular}

Keterangan :

JB 1 : Isolat bakteri ke-1

JB 2 : Isolat bakteri ke-2

JB 3 : Isolat bakteri ke-3

JB 4 : Isolat bakteri ke-4

\section{Pemurnian isolat mikroba}

Koloni mikroba yang telah diperoleh yang menunjukkan zona hambatan lalu digoreskan pada medium Nutrien Agar (NA) untuk koloni bakteri dan koloni jamur digoreskan pada medium Potato Dextrosa Agar (PDA) lalu diinkubasi selama $1 \times 24$ jam pada suhu $37^{\circ} \mathrm{C}$ untuk bakteri dan $3 \times 24$ jam pada suhu kamar untuk jamur. Setelah diinkubasi, diperoleh kultur koloni bakteri dan jamur yang murni, kemudian dikulturkan kembali dalam medium Nutrien Agar (NA) dan Potato Dextrosa Agar (PDA) miring sebagai stok.

\section{Fermentasi isolat mikroba.}

Isolat yang diperoleh kemudian difermentasi dalam medium Maltosa Yeast Broth (MYB) kemudian 
diinkubasi dan dishaker selama 1 × 24 jam dengan kecepatan 200 rpm.

Uji aktivitas antibiotika dari isolat mikroba.

Hasil fermentasi yang telah diperoleh diuji aktivitasnya dengan metode difusi agar terhadap Staphylococcus aureus, Escherichia coli, Candida albicans, Pseudomonas aeruginosa, Vibrio sp, Bacillus subtilis, Streptococcus mutans, Salmonella typhi dan Staphylococcus epidermidis.

Tabel 4. Hasil Pengukuran Diameter Zona Hambatan dari Isolat Bakteri

\begin{tabular}{|c|c|c|c|c|c|c|c|c|c|c|c|}
\hline \multirow[b]{2}{*}{ No } & \multirow[b]{2}{*}{ Isolat } & \multirow[b]{2}{*}{ R } & \multicolumn{9}{|c|}{ Diameter zona hambatan (mm) } \\
\hline & & & $S T$ & $P A$ & $S E$ & VS & $E C$ & $B S$ & $S M$ & $S A$ & $C A$ \\
\hline \multirow{4}{*}{1} & \multirow{4}{*}{ JB 1} & 1 & 12,00 & 25,00 & 13,00 & 25,00 & 25,00 & 25,00 & 15,00 & 12,00 & 10,00 \\
\hline & & 2 & 12,00 & 27,00 & 12,00 & 21,00 & 26,00 & 27,00 & 16,00 & 13,00 & 21,00 \\
\hline & & 3 & 10,00 & 25,00 & 13,00 & 31,00 & 26,00 & 28,00 & 15,00 & 13,00 & 10,00 \\
\hline & & $\tilde{y}$ & 11,33 & 25,67 & 12,67 & 25,67 & 25,67 & 26,67 & 15,33 & 12,67 & 13,67 \\
\hline \multirow{4}{*}{2} & \multirow{4}{*}{ JB 2} & 1 & 8,00 & 25,00 & 15,00 & 21,00 & 18,00 & 29,00 & 17,00 & 15,00 & 10,00 \\
\hline & & 2 & 8,00 & 25,00 & 15,00 & 21,00 & 20,00 & 28,00 & 17,00 & 15,00 & 11,00 \\
\hline & & 3 & 8,00 & 25,00 & 15,00 & 20,00 & 20,00 & 29,00 & 16,00 & 15,00 & 10,00 \\
\hline & & $\tilde{y}$ & 8,00 & 25,00 & 15,00 & 21,00 & 19,33 & 28,67 & 16,67 & 15,00 & 10,33 \\
\hline \multirow{4}{*}{3} & \multirow{4}{*}{ JB 3} & 1 & 0 & 15,00 & 12,00 & 17,00 & 17,00 & 25,00 & 15,00 & 13,00 & 0 \\
\hline & & 2 & 0 & 15,00 & 18,00 & 17,00 & 16,00 & 24,00 & 16,00 & 13,00 & 0 \\
\hline & & 3 & 0 & 15,00 & 18,00 & 16,00 & 18,00 & 23,00 & 15,00 & 13,00 & 0 \\
\hline & & $\tilde{y}$ & 0 & 15,00 & 16,00 & 16,67 & 17,00 & 24,00 & 15,33 & 13,00 & 0 \\
\hline \multirow{4}{*}{4} & \multirow{4}{*}{ JB 4} & 1 & 0 & 12,00 & 7,00 & 13,00 & 12,00 & 13,00 & 10,00 & 10,00 & 0 \\
\hline & & 2 & 0 & 12,00 & 10,00 & 15,00 & 12,00 & 15,00 & 10,00 & 10,00 & 0 \\
\hline & & 3 & 0 & 11,00 & 8,00 & 20,00 & 13,00 & 14,00 & 10,00 & 10,00 & 0 \\
\hline & & $\tilde{y}$ & 0 & 11,67 & 8,33 & 16,00 & 12,33 & 14,00 & 10,00 & 10,00 & 0 \\
\hline
\end{tabular}

Keterangan :

R : Replikasi

ỹ : Rata-rata

JB 1 : Isolat bakteri 1

JB 2 : Isolat bakteri 2

JB 3 : Isolat bakteri 3

JB 4 : Isolat bakteri 4

ST : Salmonella typhi

SE : Staphylococcus epidermidis
SM : Streptococcus mutans

$S A$ : Staphylococcus aereus

$P A \quad:$ Pseudomonas aeruginosa

VS : Vibrio sp

BS : Bacillus subtilis

EC : Escherichia coli

$C A$ : Candida albicans

Tabel 5. Hasil Pengukuran Diameter Zona Hambatan dari Isolat Jamur

\begin{tabular}{|c|c|c|c|c|c|c|c|c|c|c|c|}
\hline \multirow[b]{2}{*}{ No } & \multirow[b]{2}{*}{ Isolat } & \multirow[b]{2}{*}{$\mathbf{R}$} & \multicolumn{9}{|c|}{ Diameter zona hambatan (mm) } \\
\hline & & & $S T$ & $P A$ & $S E$ & $V S$ & $E C$ & $B S$ & $S M$ & $S A$ & $C A$ \\
\hline \multirow{4}{*}{1} & \multirow{4}{*}{ JJ 1} & 1 & 8,00 & 0 & 0 & 0 & 0 & 0 & 0 & 0 & 8,00 \\
\hline & & 2 & 8,00 & 0 & 0 & 0 & 0 & 0 & 0 & 0 & 8,00 \\
\hline & & 3 & 8,00 & 0 & 0 & 0 & 0 & 0 & 0 & 0 & 8,00 \\
\hline & & $\tilde{y}$ & 8,00 & 0 & 0 & 0 & 0 & 0 & 0 & 0 & 8,00 \\
\hline \multirow{4}{*}{2} & \multirow{4}{*}{ JJ 2} & 1 & 0 & 20,00 & 11,00 & 0 & 0 & 17,00 & 19,00 & 0 & 9,00 \\
\hline & & 2 & 0 & 17,00 & 12,00 & 0 & 0 & 17,00 & 19,00 & 0 & 9,00 \\
\hline & & 3 & 0 & 18,00 & 12,00 & 0 & 0 & 17,00 & 19,00 & 0 & 10,00 \\
\hline & & $\tilde{y}$ & 0 & 18,33 & 11,67 & 0 & 0 & 17,00 & 19,00 & 0 & 9,33 \\
\hline
\end{tabular}




\begin{tabular}{|c|c|c|c|c|c|c|c|c|c|c|c|}
\hline \multirow{4}{*}{3} & \multirow{4}{*}{ JJ 3} & 1 & 0 & 0 & 0 & 0 & 0 & 0 & 0 & 0 & 9,00 \\
\hline & & 2 & 0 & 0 & 0 & 0 & 0 & 0 & 0 & 0 & 9,00 \\
\hline & & 3 & 0 & 0 & 0 & 0 & 0 & 0 & 0 & 0 & 11,00 \\
\hline & & $\tilde{y}$ & 0 & 0 & 0 & 0 & 0 & 0 & 0 & 0 & 9,67 \\
\hline \multirow{4}{*}{4} & \multirow{4}{*}{ JJ 4} & 1 & 0 & 15,00 & 15,00 & 15,00 & 15,00 & 13,00 & 17,00 & 25,00 & 0 \\
\hline & & 2 & 0 & 12,00 & 13,00 & 15,00 & 15,00 & 13,00 & 17,00 & 11,00 & 0 \\
\hline & & 3 & 0 & 13,00 & 13,00 & 15,00 & 16,00 & 13,00 & 17,00 & 21,00 & 0 \\
\hline & & $\tilde{y}$ & 0 & 13,33 & 13,67 & 15,00 & 15,33 & 13,00 & 17,00 & 19,00 & 0 \\
\hline
\end{tabular}

Keterangan :

\begin{tabular}{|c|c|c|c|}
\hline $\mathrm{R}$ & : Replikasi & $S M$ & : Streptococcus mutans \\
\hline$\tilde{y}$ & : Rata- rata & $S A$ & : Staphylococcus aereus \\
\hline JJ 1 & : Isolat jamur 1 & $P A$ & : Pseudomonas \\
\hline JJ 2 & : Isolat jamur 2 & aeruginosa & \\
\hline JJ 3 & : Isolat jamur 3 & VS & Vibrio sp \\
\hline JJ 4 & : Isolat jamur 4 & $B S$ & Bacillus subtilis \\
\hline$S T$ & : Salmonella typhi & $E C$ & : Escherichia coli \\
\hline$S E$ & : $\quad$ Staphylococcus & $C A$ & : Candida albicans \\
\hline
\end{tabular}
epidermidis

\section{PEMBAHASAN}

Tahap awal dari penelitian ini adalah dengan melakukan penelusurani mikroorganisme yang dapat menghasilkan antibiotika dari limbah air dangke Kabupaten Enrekang, kemudian dilanjutkan dengan pemurnian isolat bakteri, fermentasi isolat bakteri, pengujian aktivitas antibiotika, dan pengecatan gram isolat bakteri.

Pada penelitian ini menggunakan sampel Limbah Air Dangke sebab menurut Suwandi (1989) sumber penghasil antibiotika antara lain berasal dari tanah, air laut, lumpur, kompos, limbah domestik, bahan makanan busuk dan lain-lain. Sampel limbah air dangke ini dipilih karena untuk mengetahui apakah limbah air dangke tersebut mengandung mikroorganisme yang dapat menghasilkan antibiotika.

Penelitian ini diawali dengan mengisolasi mikroorganisme yang terdapat pada limbah air dangke. Metode isolasi yang digunakan adalah metode tuang yang dibuat pada beberapa pengenceran yaitu pada pengenceran $10^{-1}, 10^{-2}, 10^{-3}, 10^{-4}, 10^{-5}$. Pengenceran ini dimaksudkan untuk meminimalkan jumlah mikroorganisme yang terdapat pada limbah air dangke sehingga dapat memudahkan dalam pengisolasian dan tidak terjadi penumpukan mikroba yang dapat menyulitkan dalam pengamatan, karena koloni-koloni mikroorganisme yang diisolasi hanya memberikan daerah bening disekitarnya, yang membentuk fase stasioner dimana menurut sermanti (1969) pembentukan 
antibiotika umumnya terdapat pada fase stasioner yaitu dimana mikroorganisme mulai kekurangan nutrisi sehingga mikroorganisme tersebut akan berusaha mempertahankan hidupnya dengan cara menghasilkan metabolit sekunder yang berupa bahan-bahan toksik yang dapat menghambat pertumbuhan mikroorganisme lain.

Adapun medium yang digunakan untuk mengisolasi mikroorganisme yang terdapat pada Limbah Air Dangke tersebut yaitu medium Nutrien Agar (NA) untuk bakteri dan Potato Dextrosa Agar (PDA) untuk jamur. Kedua medium tersebut mengandung nutrisi yansg dibutuhkan oleh mikroorganisme yang terdapat pada Limbah Air Dangke tersebut yaitu ekstrak beef sebagai sumber protein, pepton sebagai sumber asam amino yang terdapat dalam medium Nutrien Agar (NA) dan ekstrak kentang sebagai sumber karbohidrat, dekstrosa sebagai sumber karbon yang terdapat dalam medium Potato Dextrosa Agar (PDA).

Dari proses isolasi diatas diperoleh koloni dengan zona bening diantara koloni-koloni lainnya. Pada medium Nutrien Agar (NA) diperoleh 4 isolat bakteri yang diisolasi dari pengenceran $10^{-1}$ ( 1 isolat), $10^{-2}$ (1 isolat), $10^{-3}$ ( 1 isolat), $10^{-4}$ ( 1 isolat), sedangkan pada medium Potato Dextrosa Agar (PDA) juga diperoleh 4 isolat jamur dari pengenceran $10^{-1}$ (2 isolat), $10^{-2}$ ( 1 isolat), $10^{-5}$ ( 1 isolat)

Isolat bakteri dan jamur yang telah diperoleh diamati secara makroskopik. Pengamatan ini dilakukan untuk mengetahui bentuk morfologi isolat mikroba tersebut sehingga dapat diketahui dengan pasti bahwa keempat isolat bakteri dan jamur yang diperoleh berbeda jenisnya. Pengamatan ini meliputi warna koloni, bentuk koloni, tepi koloni, elevasi koloni, dan struktur dalam koloni. Untuk isolat bakteri I (JB 1), warna koloninya putih, berbentuk Irregular and spreading, bertepi irregular, elevasinya convex, dan struktur dalamnya opaque. Isolat bakteri II (JB 2), warna koloninya juga kuning, berbentuk irregular and spreading dengan tepi irregular, elevasinya umbonate, dan struktur dalamnya opaque. Isolat bakteri III (JB 3), warna koloninya kuning, berbentuk round, bertepi wavy (Undulate), elevasinya convex, dan struktur dalamnya opaque. Isolat bakteri IV (JB 4), warna koloninya putih, berbentuk Irregular and Spreading, bertepi Ciliate, elevasinya Convex, dan struktur dalamnya 
opaque. Untuk isolat jamur I (JJ 1), warna koloninya hijau keabu-abuan, berbentuk complex, bertepi ciliate, elevasinya umbonate, dan struktur dalamnya filamentous. Isolat jamur II (JJ 2), warna koloninya hijau tua, berbentuk round, bertepi ciliate, elevasinya convex, dan struktur dalamnya filamentous. Isolat jamur III (JJ 3), warna koloninya Hijau, berbentuk round with radiating margin, bertepi ciliate, elevasinya umbonate, dan struktur dalamnya filamentous. Isolat jamur IV (JJ 4), warna koloninya hijau muda, berbentuk round with radiating margin, bertepi wavy (undulate), elevasinya convex dan berstruktur dalam filamentous.

Selanjutnya, dilakukan pengecatan Gram pada isolat bakteri untuk mengetahui jenis Gram isolat bakteri tersebut. Pengecatan Gram isolat dibedakan ke dalam Gram positif dan Gram negatif dengan pengecatan Gram. Cat-cat yang digunakan dalam pengecatan ini adalah cat $A$ (kristal violet), cat $B$ (larutan iodium), cat $C$ (etanol), dan cat $D$ (safranin).

Tahap pertama digunakan cat A merupakan cat yang bersifat basa, kemudian penambahan cat $\mathrm{B}$ akan membentuk kompleks Kristal violetiodium di dalam sel bakteri, penambahan cat C sebagai dekolorisasi, akan melunturkan zat warna sebelumnya dan cat $D$ untuk memberikan warna kontras pada selsel dan sifatnya tidak meyerap zat warna sebelumnya. Dari hasil penelitian yang dilakukan semua isolat bakteri merupakan bakteri Gram negatif dan berbentuk kokus.

Isolat mikroba selanjutnya dimurnikan dengan cara digores pada medium Nutrien Agar (NA) dan Potato Dextrosa Agar (PDA) yang lain. Metode pemurnian yang digunakan adalah metode kuadran, karena dengan metode ini diperoleh koloni tunggal yang lebih baik. Isolat murni yang diperoleh kemudian dibuat menjadi kultur dalam medium agar miring sebagai stok.

Setelah itu isolat yang diperoleh kemudian difermentasi dalam medium Maltosa Yeast Brotbmh (MYB) selama 1×24 jam, sambil dishaker dengan kecepatan 200 rpm, agar selama fermentasi bakteri akan mencapai fase stasioner dan menghasil metabolit sekunder, hal ini sesuai dengn teori yang dikemukakan oleh Salle A.J (1961) bahwa untuk mempertahankan hidup mikroorganisme dapat membuat pertahanan sendiri dengan menghasilken metabolit sekunder 
yang mempengaruhi mikrorganisme lain sehingga mikroorganisme lain itu tidak dapat tumbuh dan berkembang biak. Bahan - bahan toksik yang dihasilkan mikroorganisme itu disebut antibiotika.

Media yang digunakan pada fermentasi adalah Maltosa Yeast Broth (MYB), karena media ini merupakan media cair yang mengandung ekstrak yeast sebagai sumber protein, maltosa dan dekstrosa sebagai sumber karbon dan pepton sebagai sumber asam amino yang dibutuhkan dalam pertumbuhan mikroba.

Hasil fermentasi kemudian diuji aktivitas antibiotikanya dengan metode difusi agar, menggunakan Antimicrobial susceptibility test discs terhadap mikroba uji seperti Bacillus subtilis penyebab bisul, Staphylococcus aureus penyebab infeksi kulit dan keracunan makanan, Streptococcus mutans menyebabkan karies pada gigi, Pseudomonas aeruginosa yang bersifat invasif dan toksigenik dapat menimbulkan kebutaan, Salmonella typhi penyebab tifoid dan infeksi saluran kemih, Escherichia coli penyebab utama diare kronik, Vibrio $s p$ merupakan bakteri penghasil enterotoksin, penyebab kolera, Staphylococcus epidermidis penyebab infeksi neonatus dan
Candida albicans penyebab vaginitis atau keputihan. Mikroba ini digunakan berdasarkan sifat-sifat patogeniknya yang diharapkan isolat mikroba dari limbah air dangke dapat menghambat pertumbuhan mikroba patogen tersebut.

Adapun medium yang digunakan adalah medium Glukosa Nutrien Agar (GNA) sebab medium ini mengandung glukosa sebagai sumber karbon, ekstrak yeast sebagai sumber protein, pepton sebagai sumber asam amino dan $\mathrm{NaCl}$ agar sifat isotonik dari mikroba uji terjaga.

Hasil pengujian aktivitas antibiotika manunjukkan bahwa isolat memberikan aktivitas terhadap mikroba uji, hal ini dapat ditunjukkan dengan terbentuknya zona hambatan. Hasil pengukuran zona hambatan dari isolat bakteri menunjukkan bahwa isolat bakteri ke-1 (JB 1) memberikan aktivitas terhadap Bacillus subtilis, Candida albicans, Vibrio sp, Salmonella typhi, Streptococcus mutans, Staphylococcus aureus, Escherichia coli, Staphylococcus epidermidis, dan Pseudomonas aeruginosa. Dan diameter zona hambatan yang yang paling besar pada isolat bakteri ke-1 (JB 1) adalah Vibrio sp. Isolat bakteri ke-2 (JB 2) memberikan aktivitas terhadap 
Streptococcus

Staphylococcus

epidermidis,

Escherichia coli, dan Pseudomonas aeruginosa, Vibrio sp, Bacillus subtilis, Staphylococcus aureus. Dan diameter zona hambatan yang yang paling besar pada isolat bakteri ke-2 (JB 2) adalah Bacillus subtilis. Isolat bakteri ke-3 (JB 3) memberikan aktivitas terhadap Streptococcus mutans, Staphylococcus epidermidis, Escherichia coli, dan Pseudomonas aeruginosa, Vibrio sp, Bacillus subtilis, Staphylococcus aureus. Dan diameter zona hambatan yang yang paling besar pada isolat bakteri ke-3 (JB 3) adalah Bacillus subtilis. Isolat bakteri ke-4 (JB 4) memberikan aktivitas terhadap Streptococcus mutans, Staphylococcus epidermidis, Escherichia coli, dan Pseudomonas aeruginosa, Vibrio sp, Bacillus subtilis, Staphylococcus aureus. Dan diameter zona hambatan yang yang paling besar pada isolat bakteri ke-4 (JB 4) adalah Vibrio sp.

\begin{tabular}{ll} 
Hasil pengukuran zona & \multicolumn{1}{c}{ jamur } \\
hambatan dari isolat & menunjukkan isolat jamur ke-1
\end{tabular} memberikan aktivitas terhadap Salmonella typhi, Candida albicans. Dan keduanya memiliki diameter zona hambatan yang sama. Untuk isolat jamur ke-2 (JJ 2) memberikan aktivitas terhadap Pseudomonas aeruginosa, Candida albicans, Bacillus subtilis, Streptococcus mutans, Staphylococcus epidermidis. Dan diameter zona hambatan yang yang paling besar pada isolat jamur ke-2 ( $\mathrm{JJ}$ 2) adalah Pseudomonas aeruginosa. Isolat jamur ke-3 (JJ 3) memberikan aktivitas terhadap Candida albicans, Isolat jamur ke-4 (JJ 4) memberikan aktivitas terhadap Staphylococcus epidermidis, Staphylococcus aureus, Pseudomonas aeruginosa, Vibrio Sp, Escherichia coli, Bacillus subtilis, Streptococcus mutans. Dan diameter zona hambatan yang yang paling besar pada isolat jamur ke-4 (JJ 4) adalah Staphylococcus aureus.

\section{KESIMPULAN}

Berdasarkan hasil penelitian yang telah dilakukan maka dapat disimpulkan bahwa : 1) Isolasi mikroba penghasil antibiotika dari limbah air Dangke Kabupaten Enrekang menghasilkan 4 isolat bakteri dan 4 isolat jamur. 2) Isolat mikroba yang diperoleh memberikan aktivitas Bacillus subtilis, Candida albicans, Escherichia coli, Salmonella typhi, Staphylococcus aureus, Staphylococcus epidermidis, Streptococcus mutans, Pseudomonas aeruginosa, Vibrio sp. 3) Untuk bakteri, 
diameter zona hambatan yang paling besar adalah isolat bakteri I (JB 1) yang aktif terhadap Vibrio $S p$. Sedangkan pada jamur, diameter zona hambatan yang paling besar adalah isolat jamur IV (JJ 4) yang aktif terhadap Staphylococcus aureus.

\section{DAFTAR PUSTAKA}

Djide, 1991. Analisis Mikrobiologi Dangke Asal Enrekang. Laporan Penelitian Fakultas MIPA. Universitas Hasanuddin. Ujung Pandang.

Fardiaz, 1989. Penuntun Praktek Mikrobiologi Pangan. Lembaga Swadaya Informasi IPB. Bogor.
Fardiaz, S. 1993. Analisa Mikroba Pangan, PT., Raga Medika, Jakarta.

Marzuki, A.M., dkk, 1977. Peningkatan Mutu Dangke. Departemen Perindustrian Ujung Pandang.

Naid, T., 1999. Potensi Bioteknologi dalam Produksi dan Pengembangan Antibiotika Baru Menuju Paradigma Sehat, Hasanuddin University Press, Makassar.

Suwandi, U., 1989. Mikroorganisme Penghasil Antibiotika, (online) (http://www.Kalbe Farma.com., diakses 11 september 2010) 